\title{
AN ARCHITECTURAL ADAPTATION STRATEGY FOR THE DYNAMICS OF THE KAHAYAN RIVER'S WATER LEVEL AT KAMPUNG PAHANDUT, PALANGKARAYA CITY
}

\author{
${ }^{1}$ Alifi Diptya Nidikara. ${ }^{2}$ Dr. Ir. Giosia Pele Widjaja, M.T. \\ ${ }^{1}$ Student in the Bachelor's (S-1) Study Program in Architecture at \\ Parahyangan Catholic University \\ ${ }^{2}$ Senior lecturer in the Bachelor's (S-1) Study Program in Architecture at \\ Parahyangan Catholic University
}

\begin{abstract}
Kalimantan (Borneo) is famous as the island of a Pulau Seribu due to the large number of rivers that run across its cities. One of the longest is the Kahayan river that flows through the city of Palangka Raya. The river as an important aspect in Kalimantan people's life has made it the starting point for the embryo of a city in the form of river side dwellings that keeps on developing amidst the dynamics of the Kahayan river that undergoes a high degree of change in terms of water level during the dry and rainy seasons. The issue that arises is the addition and loss of space due to the changes of the river water level. The purpose of this research is to describe the adaptation strategies used by the writer in Kampung Pahandut that is unique when compared other kampongs (villages) due to its condition of having dry and flooded streets in the dwelling area. This research is qualitative in nature, employing the narrative descriptive method. The data collection technique uses purposive sampling to collect the physical and activity data. The physical and activity data were gained through a survey of the research object as well as picture taking, field observation, as well as the medium ofinterviews conducted with the Kampung Pahandut villagers. The data was then processed by classifying the numerous changes that had happened in both physical and activity-related terms as well as analyzing and concluding the adaptation strategies. It was found that in Kampung Pahandut there were both physical and activity-related changes as efforts to accommodate its people to enable them to survive the dry and flooding condition due to the changes of the river water level. Within these efforts there was also architectural adaptation based on the study consisting of three adaptation strategies, namely: being adjustable, refittable, and movable.
\end{abstract}

Keywords: architectural adaptation, changes in water level, Kahayan River, Kampung Pahandut

\section{STRATEGI ADAPTASI ARSITEKTURAL TERHADAP DINAMIKA PERUBAHAN KETINGGIAN PERMUKAAN AIR SUNGAI KAHAYAN DI KAMPUNG PAHANDUT, KOTA PALANGKARAYA}

\author{
${ }^{1}$ Alifi Diptya Nidikara. ${ }^{2}$ Dr. Ir. Giosia Pele Widjaja, M.T. \\ ${ }^{1}$ Mahasiswa S1 Program Studi Arsitektur Universitas Katolik Parahyangan. \\ ${ }^{2}$ Dosen Pembimbing S1 Program Studi Arsitektur Universitas Katolik Parahyangan.
}

${ }^{1}$ Corresponding Author: diptyanidi@gmail.com 


\begin{abstract}
Abstrak- Kalimantan terkenal dengan sebutannya sebagai Pulau Seribu Sungai karena banyaknya sungai yang mengalir di kota-kotanya. Salah satu sungai terpanjang adalah Sungai Kahayan yang melintasi Kota Palangka Raya. Sungai sebagai aspek penting dalam kehidupan masyarakat di Kalimantan membuat Sungai Kahayan ini menjadi awal perkembangan embrio kota berupa sebuah permukiman tepi sungai dan terus berkembang ditengah dinamika Sungai Kahayan yang memiliki perubahan permukaan air sungai yang cukup tinggi pada saat musim kemarau dan musim hujan. Dengan isu muncul dan hilangnya ruang darat akibat perubahan level muka air sungai. Tujuan penelitian ini adalah untuk mendeskripsikan strategi adaptasi yang dilakukan oleh penulis di Kampung Pahandut yang memiliki keunikan tersendiri karena kondisi kampungnya yang dibandingkan dengan permukiman tepi sungai lainnya di Kalimantan tidak memiliki kondisi banjir dan kering pada area permukimannya. Penelitian ini merupakan jenis penelitian kualitatif dengan metoda deskriptif naratif. Teknik pengumpulan data menggunakan purposive sampling untuk mengumpulkan data fisik dan data kegiatan. Data fisik dan data kegiatan ini didapatkan melalui survei ke objek studi dan melakukan pengambilan gambar, observasi lapangan, serta wawancara warga Kampung Pahandut. Data ini diolah dengan menglasifikasikan berbagai macam perubahan yang terjadi baik secara fisik maupun kegiatan dan menganalisa serta menarik kesimpulan strategi adaptasinya. Ditemukan bahwa Kampung Pahandut terdapat perubahan baik secara fisik dan kegiatan yang terjadi sebagai usaha untuk mewadahi kegiatan masyarakatnya agar dapat bertahan hidup menghadapi kondisi banjir dan kering akibat perubahan permukaan air sungai. Dalam usahanya ini terjadi adaptasi arsitektural dimana berdasarkan hasil kajian ditemukan tiga strategi adaptasi, yaitu adjustable, refitable dan movable.
\end{abstract}

Kata-kata kunci: Adaptasi Aristektural, Perubahan Ketinggian Permukaan Air, Sungai Kahayan, Kampung Pahandut

\title{
1 PENDAHULUAN
}

Kalimantan sebagai pulau terbesar di Indonesia juga terkenal dengan sebutannya sebagai Pulau Seribu Sungai karena banyaknya sungai yang mengalir di pulau ini. Salah satu sungai terpanjang di Pulau Kalimantan ini adalah Sungai Kahayan yang terdapat di Palangkaraya, ibukota Kalimantan Tengah.

Seperti sungai-sungai lainnya di Pulau Kalimantan, Sungai Kahayan merupakan nadi utama dari Kota Palangkaraya, yang berfungsi sebagai jalur transportasi utama, sebelum kemudian transportasi kota dilengkapi dengan jalur darat dan udara. Hal ini menyebabkan banyak permukiman yang tumbuh di sepanjang tepi Sungai Kahayan karena banyaknya aktivitas yang terjadi di kawasan sungai.

Permukiman yang berada di tepian Sungai Kahayan yang paling pertama merupakan sebuah perkampungan yang bernama Kampung Pahandut, yang juga merupakan permukiman pertama pada kawasan yang kemudian menjadi Kota Palangkaraya ini. Daerah sekitar kawasan Kampung Pahandut tersebut yang kemudian menjadi titik awal pertumbuhan embrio kota modern yang dibangun oleh Soekarno pada tahun 1958. Namun pembangunan ini mengarah ke arah selatan kota menjauhi tepi sungai, sehingga kawasan permukiman tepi sungai ini tidak terintervensi oleh adanya pembangunan kota modern Palangkaraya.

Pembangunan yang menjauhi sungai ini memberikan kesan tertinggal pada kawasan permukiman tepi Sungai Kahayan ini. Dimana kawasan sungai cenderung menjadi bagian belakang dari arah pembangunan kota modern Palangkaraya. Semakin padatnya penduduk kota, kawasan kampung yang juga perkembangan kawasannya dibatasi oleh kawasan modern, membuat kawasan kampung menjadi semakin padat dan mengarah semakin ke tengah sungai menghasilkan rumah-rumah yang berlapis-lapis di tepian sungai.

Kawasan modern yang membelakangi sungai dan perkembangan transportasi jalur darat yang pada saat ini lebih dominan dibandingkan dengan transportasi jalur air pada kawasan ini 
membuat rumah-rumah secara dominan berorientasi menghadap ke arah jalan, membuat sungai menjadi area belakang bagi rumah. Area belakang ini yang kemudian menjadi area untuk pembuangan limbah, baik itu limbah rumah tangga, limbah domestik kampong seperti sisa-sisa konstruksi maupun menjadi daerah kakus. Sehingga area yang sudah semakin padat ini kemudian berkembang menjadi daerah yang kumuh dan kotor.

Kalimantan memiliki karakteristik yang didominasi oleh lahan berupa lahan basah yang meliputi lahan rawa maupun lahan bergambut. Area berupa lahan basah ini memiliki berapa karakteristik unik, diantaranya adalah dataran yang memiliki elevasi rendah dan dipengaruhi pasang surut air laut di beberapa area dekat pantai serta dipengaruhi oleh musim yang terletak jauh dari pantai juga wilayah didominasi oleh lahan gambut. Untuk itu, banyak sungai besar di Kalimantan karena berada di dataran rendah dan langsung terhubung dengan laut merupakan sungai dengan karakterisitik pasang surut.

Sungai Kahayan sendiri karena bagian hilirnya yang langsung terhubung dengan laut ke Selat Jawa, sungai ini memiliki karakteristik sebagai sungai pasang surut. Pasang surut sungai ini dialami setiap harinya sebanyak dua kali sehari dengan jumlah yang tidak terlalu signifikan. Namun keunikan lainnya adalah pada musim kemarau, sungai akan mengalami pendangkalan permukaan air karena mengalami surut. Dan sebaliknya pada saat musim hujan permukaan air sungai akan naik hingga mencapai pada daerah aliran sungainya.

Naik dan turunnya permukaan air ini secara langsung akan mempengaruhi juga kawasan permukiman yang berada di tepi Sungai Kahayan ini. Baik secara fisik, mempengaruhi ruang timbul dan hilang terkait dengan pasang dan surutnya permukaan air sungai. Namun juga secara pola perilaku penghuni kawasan tersebut, dimana kegiatan sehariharinya akan dipengaruhi oleh tinggi dan rendahnya permukaan air sungai pasang surut Kahayan ini.

Pada kenyataannya, penduduk Kampung Pahandut di tepi Sungai Kahayan ini sudah hidup berpuluh-puluh tahun dengan kondisi lingkungan rumah yang terkadang berbasis air dan terkadang berbasis darat. Dengan kondisi ini, budaya bermukim di tepi sungai Kahayan ini tidak hanya dipengaruhi oleh fakta bahwa penghuni bermukim pada kawasan air dan dipengaruhi sungai, namun juga kepada kondisi dinamis sungai yang mengalami pasang surut secara musiman. Keadaan ini akan berdampak pada bentuk fisik dan pola perilaku penghuni yang tinggal di permukiman tepi sungai tersebut yang secara musiman akan berbeda. Pada akhirnya, diharapkan penelitian ini dapat mejadi pertimbangan untuk melestarikan budaya bermukim di tepi sungai tentunya dengan beberapa usaha perbaikan kualitas permukiman.

Berdasarkan latar belakang dan rumusan masalah dari penelitian ini, maka tujuan utama dari penelitian adalah mengidentifikasi perubahan tataan yang terjadi di Kampung Pahandut. Kemudian mengidentifikasi bentuk adaptasi asitektural di permukiman tepi sungai terhadap kondisi banjir dan kering akibat Sungai Kahayan. 


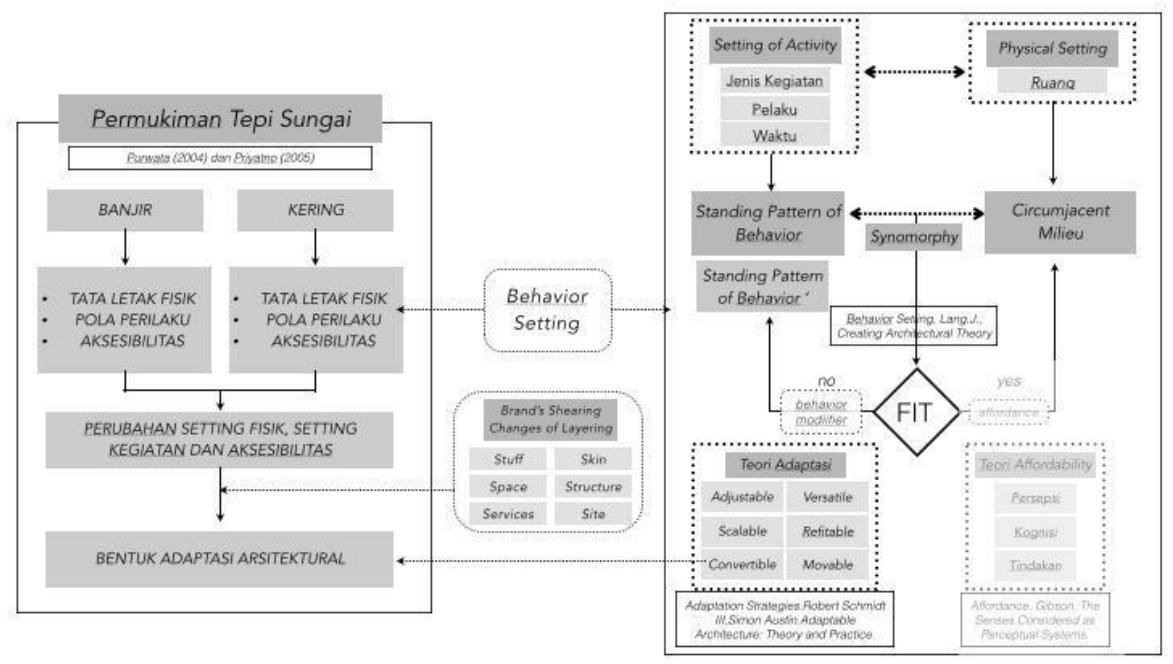

Figur 1. Kerangka Teoritik

Manfaat yang diharapkan dapat diberikan oleh penelitian ini adalah dapat diketahuinya poin-poin yang menjadi bentuk adaptasi dari kawasan permukiman dari tepi sungai Kahayan. Selain itu dengan diketahuinya bentuk adaptasi yang unik dan hanya terjadi di Sungai Kahayan ini dapat menjadi pertimbangan untuk menjadikan budaya bermukim tepi air Sungai Kahayan yang unik ini kawasan yang dilestarikan.

\section{PERMUKIMAN TEPI SUNGAI DAN ADAPTASI ARSITEKTURAL 2.1 PERMUKIMAN TEPI SUNGAI}

Kondisi alam di daerah tepi sungai secara topografi merupakan pertemuan antara darat dan air dimana kawasan ini merupakan dataran rendah dan landai sehingga sering terjadi erosi dan sedimentasi yang menimbulkan pendangkalan sungai. Bila dilihat secara hidrologis maka daerah tersebut merupakan daerah pasang surut dengan muka air tanah tinggi. Secara umum tanah di sekitarnya terdiri dari batuan lepas, tanah lembek, serta rawan terhadap bencana alam. Sedangkan bila dilihat secara klimatologis, daerah tepi sungai memiliki dinamika iklim, cuaca, angin, suhu, dan kelembaban tinggi.

Permukiman tepi sungai termasuk ke dalam permukiman yang memiliki pola persebaran linear karena penyebarannya yang sejajar mengikuti arah aliran sungai.

\section{Karakteristik Fisik Permukiman Tepi Sungai.}

Secara fisik, permukiman pada tepi sungai juga memiliki perbedaan yang tidak terdapat pada jenis permukiman lain (Clare A gunn, 1988), diantaranya:

(1) Karakter media air yang bersifat dinamis membuat pola pengembangan massa juga bersifat dinamis.

(2) Memiliki karakter visual yang unik bila dipandang secara keseluruhan bila melihat dengan adanya ruang darat dan ruang air.

(3) Massa bangunan, kegiatan, dan aktivitas yang berorientasi pada air.

(4) Pemandangan yang khas dengan merefleksikan bangunan-bangunan daerah tepian. 
(5) Adanya penghubung antara daerah tepian dan daerah air yang ditandai dengan jembatan dan pelabuhan.

(6) Perencanaan pembangunan perlu ditinjau dari beberapa aspek, yaitu:

(a) Aspek lingkungan memperhatikan perubahan-perubahan yang akan terjadi sehingga tidak merusak ekosistem yang ada.

(b) Aspek perencanaan kota yang dapat membantu menyelesaikan masalah kota pada penyediaan sarana dan prasarana lapangan pekerjaan yang mempunyai kualitas baik bagi masyarakat umum.

(c) Aspek teknologi perlu dikaji untuk memanfaatkan kawasan tersebut sebagai pengendali banjir, penyediaan air bersih, drainase, dan lain-lain.

Rumah sebagai tempat bernaung atau shelter sangat erat kaitannya dengan tempatnya berada atau lingkungan sekitarnya. Sehingga keberadaan rumah yang berada di tepi sungai tentunya akan sangat mempengaruhi konstruksi massa bangunannya. Karakterisitik rumah atau bangunan di atas air ataupun di tepi sungai dapat dibagi menjadi dua tipe, diantaranya:

(1) Bangunan panggung, merupakan bangunan dengan konstruksi yang mempunyai lantai dasar di atas permukaan air.

(2) Bangunan rakit (raft), merpakan bangunan dengan konstruksi bagian pondasi berbentuk rakit (raft) yang mengapung di atas permukaan air.

Bila ditinjau dari kondisi sosial, ekonomi, dan budaya dari permukiman tepi sungai sendiri, kawasan ini memiliki kelebihan lokasi sebagai pusat pertumbuhan kegiatan ekonomi karena dekat dengan jalur transportasi. Maka dari itu, penduduk kawasan ini cenderung memiliki kegiatan sosial ekonomi yang khas dan berorientasi ke air. Selain itu karena hidupnya yang dekat dengan air, tentunya akan memunculkan budaya air yang khas. Oleh karena itu, masyarakat yang tinggal di kawasan tepi sungai lebih banyak bekerja dengan memanfaatkan lingkungan air di sekitarnya seperti memancing dan memelihara ikan ataupun berdagang.

\section{Karakteristik Permukiman Tepi Sungai Kahayan}

Rumah apung adalah salah satu jenis rumah yang ada di kawasan permukiman tepi Sungai Kahayan selain dengan rumah panggung. Rumah apung atau disebut juga rumah lanting merupakan rumah tradisional Suku Dayak yang dibangun di atas air. Rumah apung ini dapat dibedakan menjadi beberapa jenis berdasarkan fungsinya, yaitu (1) sebagai rumah; (2) sebagai keramba ikan; (3) sebagai toko dan warung; dan (4) sebagai tambatan klotok atau perahu (dermaga).

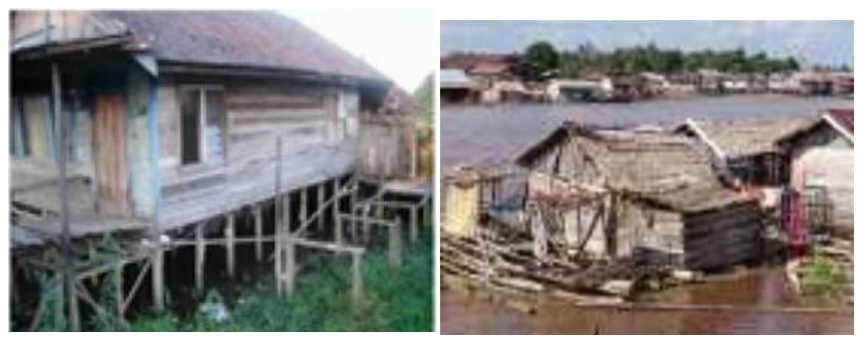

Figur 2 Rumah Panggung dan Rumah Apung/Lanting (sumber: Noor Hamidah, 2016) 
Pada permukiman tepi Sungai Kahayan ini, permukiman termasuk kedalam permukiman dengan pola linear yang mengikuti arah aliran sungainya. Dengan struktur kotanya adalah kota yang berada di pinggiran sungai.

Pada permukiman ini, rumah dengan jenis rumah panggung semuanya memiliki Surat Kepemilikan Tanah (SKT) yang dikeluarkan oleh Kelurahan Pahandut serta Surat Keputusan Gubernur Tahun 1960 yang menetapkan kepemilikan tanah. Sedangkan rumah dengan jenis rumah apung tidak memiliki Surat Kepemilikan Tanah (SKT). Oleh karena itu, permukiman dapat dibagi dua menjadi permukiman formal, yaitu permukiman dengan massa bangunan rumah panggung. Serta permukiman informal dengan massa bangunan rumah apung.

Pola jalan pada kawasan yang cenderung sederhana atau mudah dalam pembagian blokblok bangunan adalah linier. Berdasarkan temuan di lapangan terdapat tiga tipe jalan di kawasan permukiman tepian sungai, yaitu: (1) Tipe 1 yaitu, jalan utama dengan lebar jalan 2,55m. Jalan utama membagi kawasan menjadi beberapa blok dan jalan-jalan kecil yang yang dibangun untuk akses kerumah dengan kualitas jalan yaitu jalan aspal; (2) Tipe 2 yaitu, jalan lingkungan terbuat dari cor beton sepanjang rumah panggung dengan lebar yaitu 1,5-3m; dan (3) Tipe 3 yaitu jalan lingkungan dengan lebar 60-1,5m terbuat dari kayu di sepanjang permukiman Sungai Kahayan.

Karakteristik masyarakat pada permukiman tepi Sungai Kahayan termasuk ke dalam masyarakat yang cukup aktif dalam kehidupan sosialnya. Hal ini terlihat dari tersedianya fasilitasfasilitas sosial yang tersedia di wilayah kampung. Fasilitas sosial mengindikasikan telah tersedianya prasarana sebagai tempat bersosialisasi di lingkungan.

\section{Adaptasi Arsitektural di Kampung Pahandut}

Schmidt dan Austin (2016) menjelaskan bahwa dalam proses adaptasi terdapat enam (6) strategi atau tipe dari sebuah adaptasi, diantaranya:

\section{(1) Adjustable}

Pada bagian ini adaptasi berupa penataan ulang perabot dalam sebuah ruangan dengan tujuan agar dapat mengakomodasi fungsi yang berbeda-beda. Dengan kata lain berupa perubahan pada fungsi maupun pengguna (change of task/user). Dalam hal ini yang menjadi perubahan paling utama adalah apa yang menjadi isi dalam suatu ruang tersebut, atau dapat dikatakan stuff. Perubahan elemen pengisi dalam kasus ini dapat berupa elemen-elemen fisik yang membentuk ruang tersebut, dimana elemen fisik dapat berupa elemen fix, elemen semifix, dan elemen informal.

\section{Versatile}

Adaptasi dilakukan dengan mengubah layout spasial dalam sebuah ruang untuk variasi aktivitas atau change of space. Dalam hal ini, tata ruang baik itu elemen pengisi dan elemen pembentuk ruangnya sendiri mengalami perubahan untuk dapat mengakomodasi kegiatan baru yang dibutuhkan. Perubahan yang terjadi akan menyangkut perubahan elemen pengisi (stuff) dan tata ruangnya (space plan). Sama seperti poin sebelumnya, perubahan elemen pengisi dapat terdiri dari perubahan elemen fix, elemen semi fix, serta elemen informal. Sedangkan perubahan tata ruang dapat diamati melalui perubahan bentuk maupun perubahan elemenelemen yang dapat mendefinisikan ruang tersebut, seperti elemen horizontal maupun elemen vertikal pada ruang.

\section{(3) Refitable}

Adaptasi ini berupa perubahan akan kemampuan bangunan dengan mengubah ruang, servis, atau kulit bangunan. Hal ini biasanya akan mempengaruhi aspek legalitas bangunan, kondisi 
lingkungan, teknologi, dan material (change of performance). Perubahan yang terjadi dalam hal ini adalah tata ruangnya (space plan), fungsi yang dilayani ruang (services), dan pelingkupnya (skin/façade). Dimana perubahan-perubahan di atas dapat dilihat dari elemenelemen fisik pembentuk ruangnya maupun kegiatan yang terjadi dalam ruang tersebut menyangkut fungsi dan kegunaan ruang yang diamati.

\section{(4) Convertible}

Bangunan yang beradaptasi dengan mengubah ruang agar sesuai dengan fungsi baru (change of use). yang sesuai dengan permintaan pasar, permintaan sosial, serta kepemilikan baru. Perubahan yang terjadi pada adaptasi ini adalah perubahan terkait dengan tata ruangnya (space plan), fungsi yang dilayani ruang (services), dan pelingkupnya (skin/façade). Namun berbeda dengan bentuk adaptasi sebelumnya yaitu refitable, convertible ini lebih kepada perubahan yang bersifat lebih lama dan terjadi pada bangunan atau skala yang lebih besar bukan elemen-elemen pada bangunan. Dimana yang berubah adalah kegunaan (change of use) dalam jangka waktu yang lebih panjang.

\section{(5) Scalable}

Adaptasi terjadi dengan mengubah ukuran ruangnya atau change of size pada studi kasus yang ada hal ini sering terjadi karena kondisi pasar, perubahan anggaran, serta kondisi sosial yang memerlukan ruangan lebih kecil atau lebih besar. Dalam hal ini, yang berubah adalah tata ruangnya (space plan), fungsi yang dilayani ruang (services), dan pelingkupnya (skin/façade), serta struktur perlingkupnya (structure).

Perubahan ini terkait karena, ruang perlu mengakomodasi kegiatan baru yang lebih besar ataupun bervariasi sehingga perlu diubah pula secara struktur dan pelingkupnya untuk berubah secara ukuran.

\section{(6) Movable}

Merupakan adaptasi yang paling jarang terjadi karena menyangkut perubahan lokasi dari bangunan tersebut. Pada dasarmya memiliki prinsip seperti pendirian yang mudah dan pembongkaran yang cepat. Poin ini terkait erat dengan refitable, solusi struktur, akses dan skala komponennya. Yang terjadi pada movable ini adalah adanya perubahan menyangkut struktur (structure) dan tapak (site). Perubahan ini dapat kita amati bila ada perubahan struktur yang menjadi penopang beban ataupun yang menjadi infrastruktur yang mewadahi kegiatan. Selain itu perubahan tapak adalah segala perubahan tempat massa bangunan terhadap batas-batas tempatnya berada. Tapak ini sangat erat kaitannya dengan lokasi geografisnya, batasnya, dan legalitasnya.

Tabel 1. Bentuk Adaptasi dan Atribut Perubahannya

(Sumber: Adaptable Architecture: Theory and Practice, Schmidt and Austin, 2016)

\begin{tabular}{|c|c|c|c|c|c|c|c|c|c|c|}
\hline & \multirow{2}{*}{ type of change } & \multirow{2}{*}{$\begin{array}{c}\text { decision - } \\
\text { level }\end{array}$} & \multirow{2}{*}{ B-E Scale } & \multirow{2}{*}{ Time Cycle } & \multicolumn{6}{|c|}{ Brand's Layer } \\
\hline & & & & & Stuff & Space & Services & Skin & Structure & Site \\
\hline adjustable & change of task & user & components & daily/monthly & 0 & & & & & \\
\hline versatile & change of space & user & components & $\begin{array}{l}\text { daily/monthly } \\
\text { dail }\end{array}$ & 0 & 0 & & & & \\
\hline refitable & $\begin{array}{c}\text { change of } \\
\text { performance }\end{array}$ & user/owner & components & 7 years & & 0 & 0 & 0 & & \\
\hline convertible & change of use & user/owner & building & 15 years & & 0 & 0 & 0 & & \\
\hline scalable & change of size & owner & building & 15 years & & 0 & 0 & 0 & 0 & \\
\hline movable & change of location & owner & building & 30 years & & & & & 0 & 0 \\
\hline
\end{tabular}


Pada tabel diatas juga dijelaskan bahwa dalam menentukan sebuah bentuk adaptasi dapat dibantu dengan atribut-atribut perubahan yang dapat menjadi parameter untuk menentukan bentuk adaptasi yang dicari seperti apa. Atribut perubahan ini diambil dari Shearing Layers of Change yang dituliskan oleh Stewart Brand dalam bukunya How Buildings Learn: What Happened After They Built yang menjelaskan mengenai ppengkalsifikasian perubahan-perubahan yang dapat terjadi pada bangunan seiring berjalannya waktu.

Pada permukiman tepi sungai, kondisi dimana terdapat konteks lain berupa air yang mempengaruhi kehidupan penghuninya. Pola hidup seperti inilah yang kemudian memunculkan hidup berbudaya air. Kehidupan dengan budaya air inilah yang kemudian akan memunculkan usaha atau respon tertentu yang dilakukan manusia terhadap kondisi lingkungannya.

\section{Hubungan Manusia dengan Lingkungannya Sebagai Pendekatan Penelitian}

Dalam pembahasan terkait dengan adaptasi manusia dengan lingkungannya, adaptasi juga dapat dijelaskan melalui pola perilaku manusia di dalam lingkungannya yang kemudian akan menunjukkan bentuk-bentuk adaptasi yang membuatnya dapat bertahan dalam sebuah lingkungan binaan tersebut. Untuk itu, mengupas suatu objek penelitian dengan menggunakan teori tatar perilaku yang terkait dengan pelaku dan tata letak fisiknya untuk mengetahui bagaimana manusia beradaptasi sehingga memunculkan lingkungan fisik tertentu, dapat memunculkan tipe adaptasi yang terjadi pada sebuah lingkungan binaan manusia. Behavior setting atau tatar perilaku ini dapat dikatakan sebagai kombinasi yang stabil antara aktivitas dan tempatnya. Menurut Roger Barker, hadirnya suatu tatar perilaku mengandung empat teori pokok.

Pertama, Standing Pattern of Behavior. Muncul akibat adanya aktivitas yang terjadi secara berulang hingga membentuk sebuah pola. Pola perilaku ini dapat terdiri dari beberapa perilaku berbeda yang terjadi secara simultan, diantaranya perilaku emosional yang jelas, perilaku menyelesaikan masalah, aktivitas motorik, interaksi interpersonal, dan kegiatan memanipulasi objek. Gabungan antara perilaku-perilaku tersebut yang membentuk sebuah pola perilaku tertentu, terjadi didalam tata letak fisik tertentu, yaitu milieu atau lingkungannya.

Kedua, Circumjacent Milieu yaitu susunan ruang tertentu pada sebuah lingkungan yang menjadi tempat terjadinya aktivitas. Sebagai elemen fisik, sebuah milieu dibutuhkan untuk dapat memenuhi peran seseorang dan sangat erat kaitannya dengan aspek ruang sebagai pembentuk suatu tempat atau lingkungan. Kualitas fisik suatu tempat memenuhi kebutuhan pelaku di dalamnya dapat dilihat baik melalui arti simbolik dan ataupun kegiatan yang terjadi.

Ketiga, Synomorphy, merupakan hubungan yang kongruen antara pola perilaku dan lingkungannya tersebut. Sebuah milieu harus dapat mengakomodasi berbagai macam pola perilaku yang berbeda di dalamnya bahkan interaksi antar pelakunya. Hal itu yang membuat synomorphy ini merupakan hubungan yang kompleks.

Keempat, Time. Periode waktu adalah suatu unit pengukuran untuk mengukur panjang waktu. Waktu menjadi salah satu tolak ukur dalam melihat suatu kegiatan dan perilaku yang berulang dalam suatu pola. Suatu periode dapat di lihat secara durasi ataupun siklus - dalam hitungan detik, menit, jam, hari, minggu, bulan, tahun atau pagi, sore, siang dan malam. 


\section{METODOLOGI PENELITIAN}

Penelitian yang dilakukan dikategorikan kedalam penelitian kualitatif deskriptif. Penelitian kualitatif lebih cenderung kepada penelitian yang bersifat subjektif, dengan mendeskripsikan serta menganalisa fenomena, aktivitas, persepsi juga pemikiran orang-orang secara individual maupun kelompok. Dengan jenis penelitian ini, dapat ditarik kesimpulan mengenai hubungan antara pola perilaku, lingkungan, dan bentuk adaptasinya.

\section{KAMPUNG PAHANDUT SEBAGAI PERMUKIMAN TEPI SUNGAI KAHAYAN}

Gambaran Umum Kampung

Penelitian mengenai bentuk adaptasi ini letaknya berada di Provinsi Kalimantan Tengah, Kota Palangka Raya, tepatnya di Kelurahan Pahandut, Kecamatan Pahandut, Kampung Pahandut. Secara geografis kawasan Pahandut ini berlokasi di tikungan Sungai Kahayan di pinggir pusat kota Palangka Raya.

Permukiman pertama ini dibentuk oleh Bapa Handut yang membuka hutan pada tahun 1894 dan menjadikannya sebuah permukiman. Nama Bapa Handut ini yang kemudian menjadi asal mula nama Kampung Pahandut. Kampung ini merupakan permukiman Suku Dayak yang memiliki orientasi ke sungai dan hanya berisikan 6 buah rumah.

Keunikan yang ada pada Sungai Kahayan ini adalah bahwa sungai memiliki kondisi ekstrem yang berbeda pada saat musim hujan dan musim kemarau. Kondisi ini adalah dimana pada saat musim kemarau, permukaan air sungai akan surut lalu pada saat musim hujan permukaan air sungai akan pasang dengan rata-rata perbedaan ketinggian yang cukup signifikan, yaitu antara 24 meter. Mayoritas penduduk di Kawasan Tepi Sungai Kahayan menganut agama Islam, hal ini ditandai dengan adanya masjid di setiap wilayah RT. Mata pencaharian penduduknya didominasi oleh pedagang, nelayan ikan, dan petani ikan. Namun tidak jarang juga yang memiliki usaha sendiri seperti warung yang terletak di teras depan rumahnya dan usaha sewa klotok untuk wisata susur sungai. Rumah panggung merupakan rumah yang berada di bantaran sungai, dimana rumah ini merupakan massa permanen. Sedangkan rumah apung adalah rumah yang berada di atas permukaan air sungai. Rumah apung ini dapat berpindah tempat mengikuti arus air, namun agar tidak berpindah tempat rumah apung ini menambatkan tali pada rumah panggung atau titian jalan di sekitarnya.

\section{Gambaran Spot Amatan}

Area yang menjadi spot amatan terletak di pinggir Jl. Kalimantan RW XXI. Terdapat empat spot yang menjadi area pengamatan. 


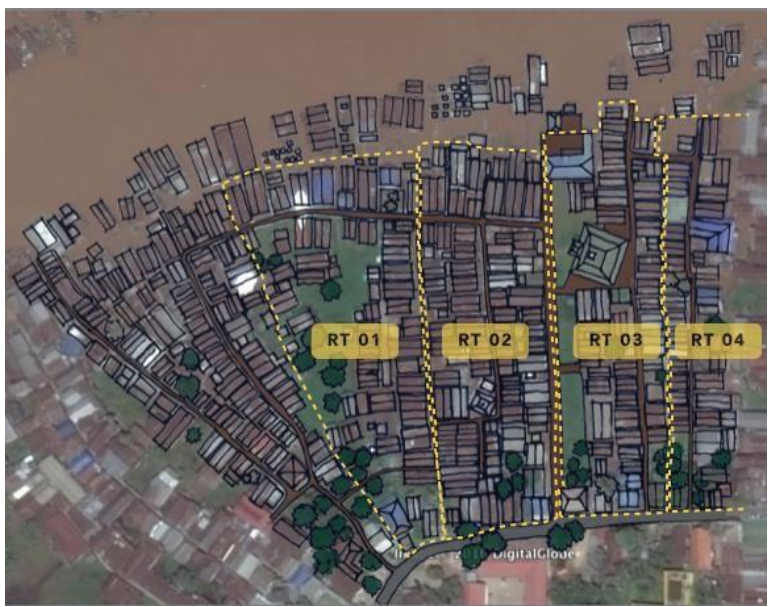

Figur 3. Peta Batas Administrasi Wilayah RW XXI

\section{BENTUK PERUBAHAN TATAAN RUANG AKIBAT KONDISI BANJIR DAN KERING}

Pembahasan studi kasus ini akan mengidentifikasi perubahan-perubahan tataan yang terjadi di tepi Sungai Kahayan yang telah diklasifikasikan untuk kemudian dianalisa adaptasi seperti apa yang dilakukan oleh masyarakat yang tinggal di tepi Sungai Kahayan ini. Kemudian tiga perubahan ini diklasifikasikan berdasar Shearing Layers of Change menurut Stewart Brand (1994).

Tabel 2.

\begin{tabular}{|c|c|c|}
\hline Faktor Analisis & Segmen & Deskripsi \\
\hline $\begin{array}{l}\text { Elemen Pengisi } \\
\text { (Stuff) }\end{array}$ & $\begin{array}{l}\text { Sub-Tatanan } 4 \\
\text { B: Ternak } \\
\text { Bebek }\end{array}$ & $\begin{array}{l}\text { Area ini merupakan area kosong pada kondisi kering yang } \\
\text { digunakan sebagai usaha sampingan dengan berternak } \\
\text { bebek. } \\
\text { Bebek-bebek ini memiliki kandangnya sendiri yang } \\
\text { menggunakan sistem apung sehingga pada saat terjadi } \\
\text { perubahan pada kondisi banjir dan kering, kandang bebek ini } \\
\text { dapat mengikuti perubahan tersebut dan mengapung } \\
\text { mengikuti permukaan air. } \\
\text { Kondisi kandang bebek yang menggunakan sistem apung ini } \\
\text { membuatnya tidak permanen dan sebagai elemen pengisi } \\
\text { ruang dapat berpindah tempat dengan mudah. }\end{array}$ \\
\hline
\end{tabular}




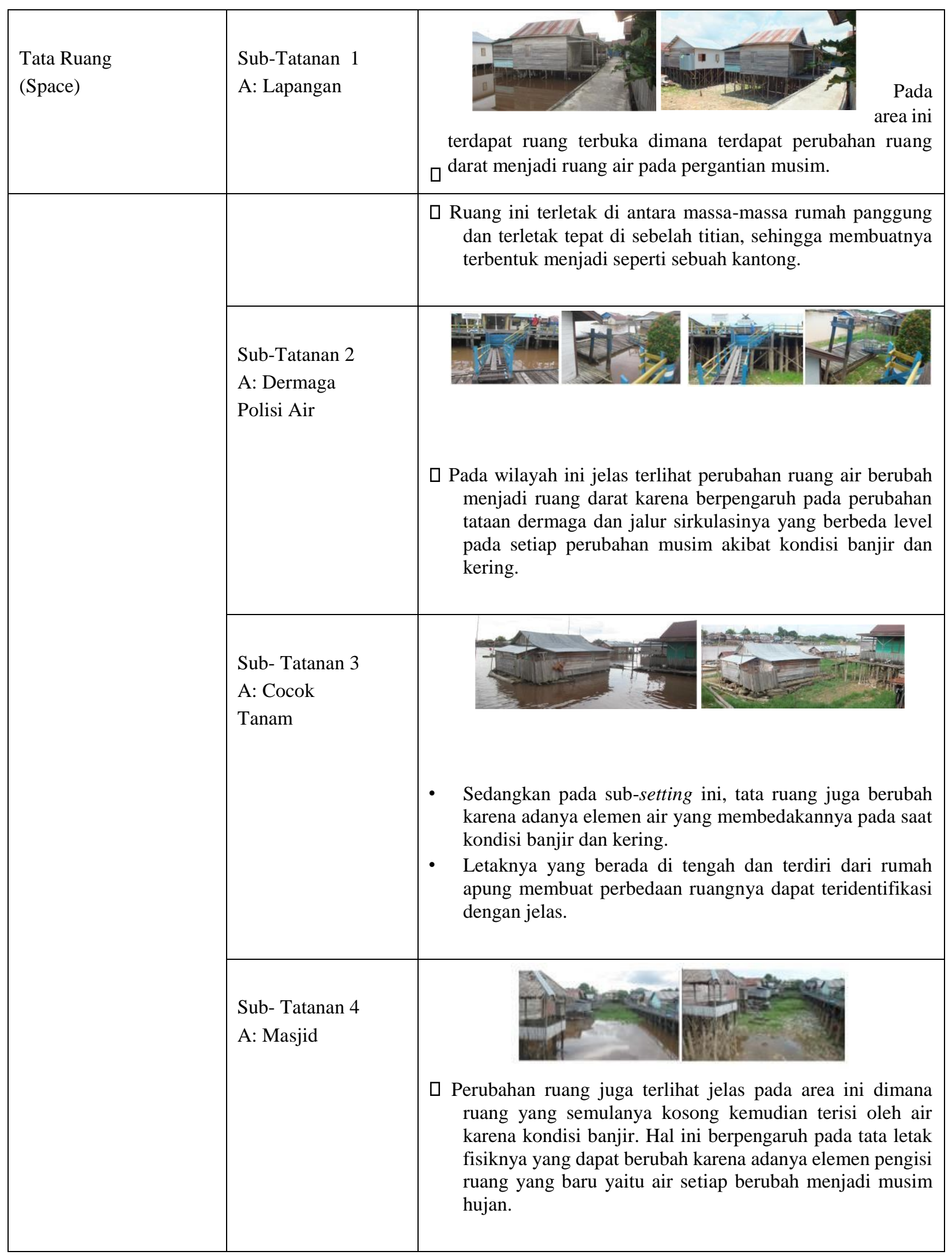




\begin{tabular}{|c|c|c|}
\hline \multirow[t]{2}{*}{$\begin{array}{l}\text { Fungsi } \\
\text { (Services) }\end{array}$} & $\begin{array}{l}\text { Sub-Tatanan } 1 \\
\text { A: Lapangan }\end{array}$ & $\begin{array}{l}\text { Perubahan services pada area ini menyangkut kegiatan } \\
\text { yang dapat diwadahi oleh ruang ini. Pada area ini pada saat } \\
\text { kondisi kering, muncul ruang darat berupa lapangan cukup } \\
\text { luas yang dapat dimanfaatkan oleh anak-anak untuk } \\
\text { bermain. } \\
\text { Sedangkan pada saat kondisi banjir, ruang tersebut tidak } \\
\text { dapat mengakomodasi kegiatan yang biasanya bisa di } \\
\text { akomodasi pada saat kondisi kering. Namun juga terdapat } \\
\text { kegiatan lain yang bisa diakomodasi hanya pada saat banjir, } \\
\text { yaitu kegiatan anak-anak yang terkadang berenang di area } \\
\text { lapangan tersebut. }\end{array}$ \\
\hline & $\begin{array}{l}\text { Sub-Tatanan } 2 \\
\text { A: Dermaga } \\
\text { Polisi Air }\end{array}$ & 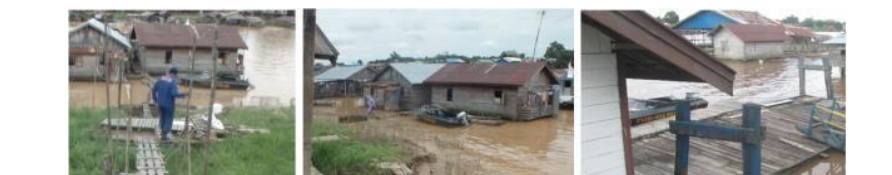 \\
\hline & & $\begin{array}{l}\text { Secara kegunaan lahan atau performanya, area ini juga } \\
\text { mengalami perubahan karena pada saat kondisi banjir } \\
\text { maupun kering area dermaga tidak memberikan akomodasi } \\
\text { bagi kegiatan yang sama. } \\
\text { Pada saat sedang kondisi kering, dermaga polisi tidak dapat } \\
\text { digunakan karena dermaga berada lebih rendah dari titian } \\
\text { utama pos polisi. Selain itu, kapal juga tidak dapat mencapai } \\
\text { dermaga karena letaknya yang terlalu dekat dengan } \\
\text { permukaan tanah. } \\
\text { Q Sedangkan pada saat kondisi banjir, dermaga dapat } \\
\text { beroperasi seperti biasa karena ketinggian elevasi permukaan } \\
\text { air sungai yang cukup tinggi hingga bisa diakses dari titian } \\
\text { utama dan air memilliki kedalaman yang cukup untuk kapal } \\
\text { bertambat di dermaga }\end{array}$ \\
\hline & $\begin{array}{l}\text { Sub- Tatanan } 3 \\
\text { A: Cocok } \\
\text { Tanam }\end{array}$ & $\begin{array}{l}\text { Bila dilihat secara sercices, area ini mengakomodasi kegiatan } \\
\text { yang hanya bisa terjadi pada saat kondisi sedang kering saja. } \\
\text { Sehingga terdapat perubahan ruang dalam mengakomodasi } \\
\text { kegiatan bercocok tanam sebagai penghasilan tambahan } \\
\text { pemiliki rumah apung tersebut. Pada saat kondisi sedang } \\
\text { banjir, area yang terisi oleh air tidak dapat digunakan dan } \\
\text { hanya menjadi ruang air saja. }\end{array}$ \\
\hline
\end{tabular}




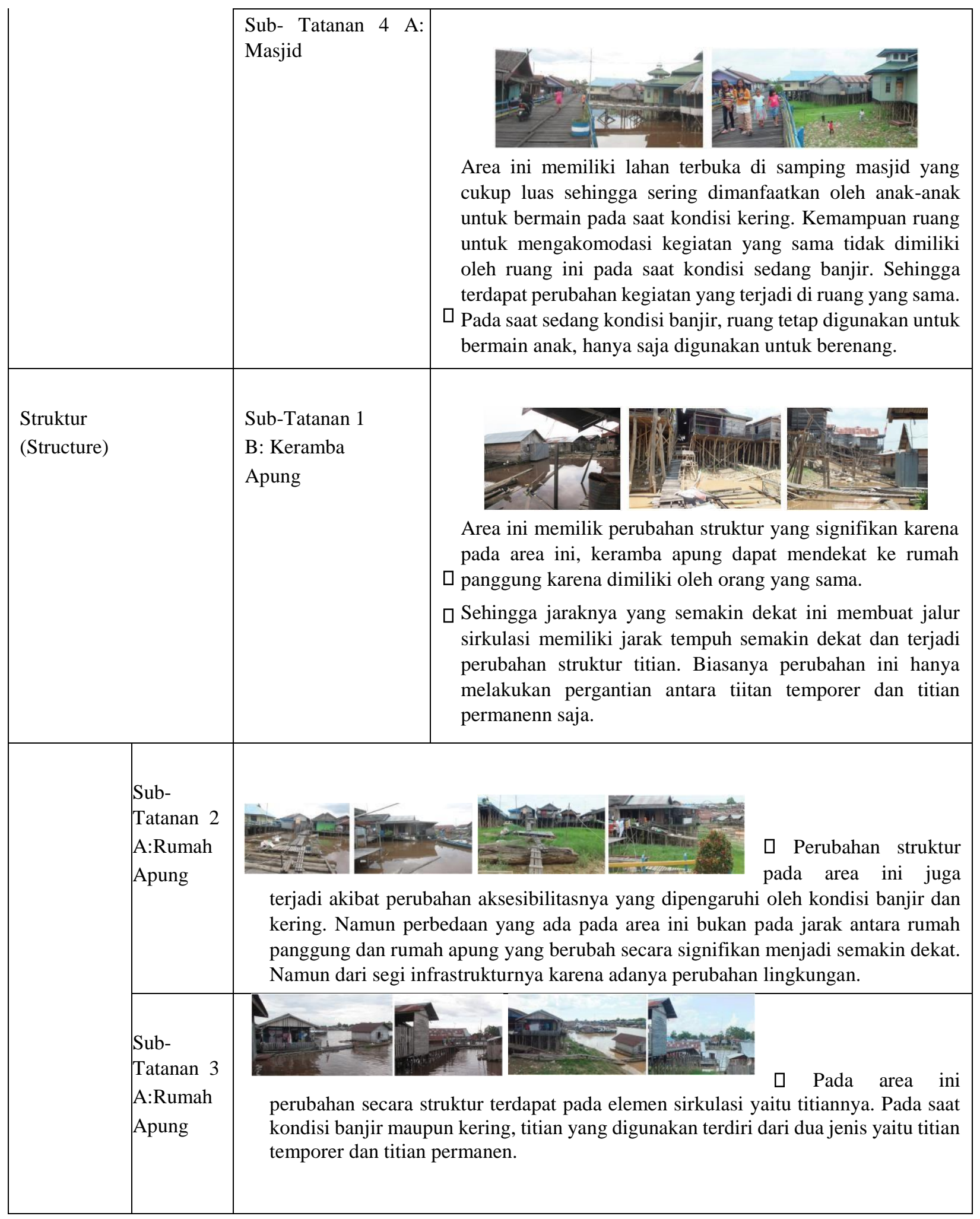




\begin{tabular}{|c|c|c|}
\hline \multirow[t]{3}{*}{ Tapak (Site) } & \begin{tabular}{|l} 
Sub- \\
Tatanan 1 \\
B:Keramba \\
Apung
\end{tabular} & $\begin{array}{l}\text { Secara site atau tapak, area ini memiliki elemen berupa titian dan rumah apung yang } \\
\text { dapat mengiktui permukaan air sungaimya, baik pada saat kondisi banjir maupun } \\
\text { kondisi kering. Berubahnya tempat rumah apung berada yang menyesuaikan dengan } \\
\text { elevasi permukaan air sungai menandakan adanya perubahan secara vertikal. Khusus } \\
\text { pada area ini, karena keramba apung merupakan bangunan yang dimiliki secara } \\
\text { pribadi oleh rumah panggung di dekatnya, maka pada saat kondisi banjir, keramba } \\
\text { apung biasanya didekatkan kearah rumah panggung agar lebih dekat sekaligus } \\
\text { mengamankan ikan yang ada dalam keramba. Hal ini menunjukkan adanya } \\
\text { perubahan site bagi elemen pada area ini. }\end{array}$ \\
\hline & $\begin{array}{l}\text { Sub- } \\
\text { Tatanan } 2 \\
\text { A:Rumah } \\
\text { Apung }\end{array}$ & $\begin{array}{l}\text { Pada area } \\
\text { elemen fisik pada area ini berupa rumah apung dan titian temporer yang karena } \\
\text { struktur pembentuknya dapat berubah mengikuti permukaan air sungai. Oleh karena } \\
\text { itu, terdapat perubahan site secara vertikal akibat berpindahnya rumah apung } \\
\text { menjadi lebih tinggi pada saat banjir dibandingkan pada saat kering, }\end{array}$ \\
\hline & $\begin{array}{l}\text { Sub- } \\
\text { Tatanan } \\
3 \\
\text { A:Rumah } \\
\text { Apung }\end{array}$ & $\begin{array}{l}\text { Secara site atau tapak, area ini memiliki elemen berupa titian dan } \\
\text { rumah apung yang dapat mengiktui permukaan air sungaimya, } \\
\text { baik pada saat kondisi banjir maupun kondisi kering. } \\
\text { Berubahnya tempat rumah apung berada yang menyesuaikan } \\
\text { dengan elevasi permukaan air sungai menandakan adanya } \\
\text { perubahan secara vertikal. }\end{array}$ \\
\hline
\end{tabular}




\section{Temuan}

Tenuan pada bab ini dibuat dalam bentuk tabel dengan mengkaji bentuk perubahan apa saja yang terjadi dalam sebuah sub-setting tersebut.

Tabel 3.

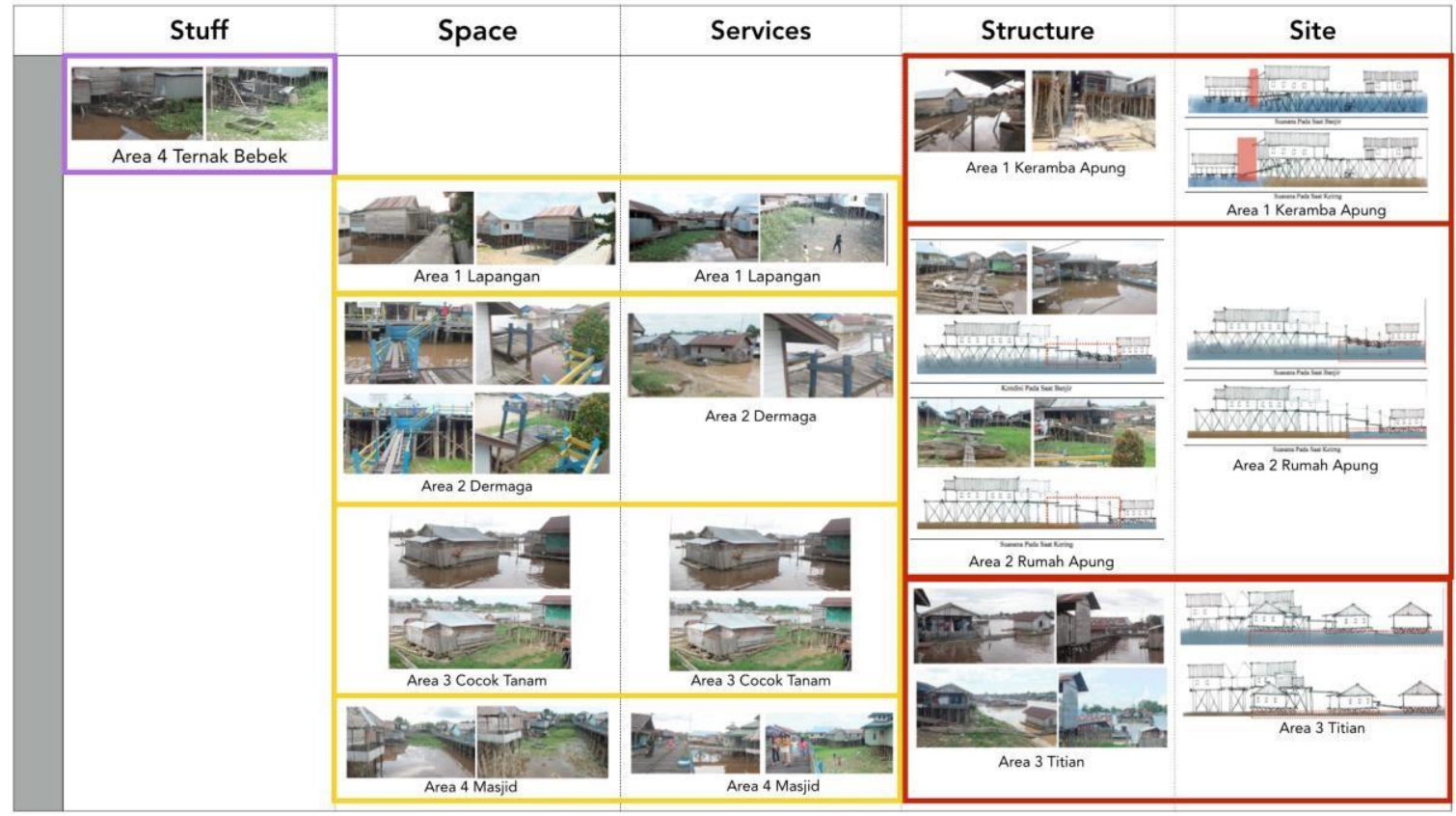

\section{RAGAM BENTUK ADAPTASI ARSITEKTURAL DI KAMPUNG PAHANDUT}

Tabel 4.

\begin{tabular}{|l|l|l|}
\hline $\begin{array}{l}\text { Faktor } \\
\text { Analisis }\end{array}$ & Segmen & Deskripsi \\
\hline Adjustable & $\begin{array}{l}\text { Sub-Tatanan } \\
\text { 4 B: Ternak } \\
\text { Bebek }\end{array}$ & \\
\hline
\end{tabular}




\begin{tabular}{|c|c|c|c|}
\hline & & - & 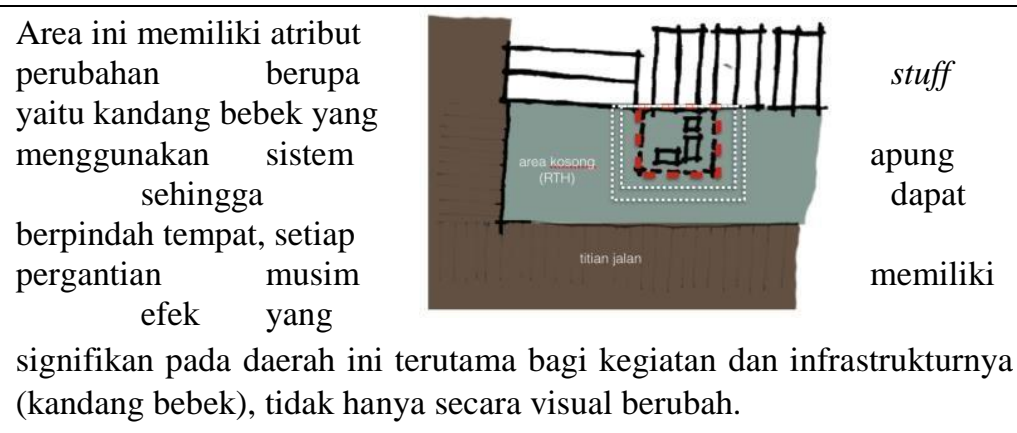 \\
\hline \multirow[t]{3}{*}{ Refitable } & $\begin{array}{l}\text { Sub-Tatanan } 1 \text { A: } \\
\text { Lapangan }\end{array}$ & 口 & $\begin{array}{l}\text { Pada area lapangan ini terlihat jelas perubahan pada ruangnya, dimana } \\
\text { ruang terbuka ini berubah dari ruag darat menjadi ruang air dan } \\
\text { sebaliknya apabila berganti musim. Air sebagai elemen pengisi ruang } \\
\text { menjadi elemen yang memberikan perubahan signifikan. } \\
\text { Selain itu ada dan tidaknya air juga mempengaruhi performa ruang } \\
\text { secara keseluruhan, dimana bila sedang dalam kondisi kering makan } \\
\text { lapangan dapat dimanfaatkan untuk anak-anak bermain bola, sedangkan } \\
\text { pada saat kondisi banjir lapangan tidak digunakan sama sekali. }\end{array}$ \\
\hline & $\begin{array}{l}\text { Sub-Tatanan } \\
2 \text { A: Dermaga } \\
\text { Polisi Air }\end{array}$ & 口 & $\begin{array}{l}\text { Perubahan yang terjadi pada area dermaga polisi air adalah perubahan } \\
\text { ruang dan perubahan servis. Dimana perubahan ruang sama seperti } \\
\text { perubahan pada area sebelumnya yaitu peruabahn ruang darat menjadi } \\
\text { ruang air dan sebaliknya. Selain itu perubahan juga mempengaruhi } \\
\text { performa ruang tersebut dengan berubahnya kegunaan ruang. Pada area } \\
\text { ini, apabila sedang dalam kondisi banjir, dermaga polisi dapat digunakan } \\
\text { secara fungsional dengan baik. Berbeda dengan pada saat kondisi banjir } \\
\text { dimana polisi perlu menggunakan dermaga rumah apung yang berada di } \\
\text { seberang dermaga untuk memarkirkan kapalnya. }\end{array}$ \\
\hline & $\begin{array}{l}\text { Sub- Tatanan } \\
3 \text { A: Cocok } \\
\text { Tanam }\end{array}$ & $\square$ & $\begin{array}{l}\text { Pada area ini, perubahan yang terjadi pada ruang adalah pergantian } \\
\text { antara ruang darat dan ruang air yang mempengaruhi kegunaan } \\
\text { ruangnya, dimana pada saat kondisi kering bagian surut dapat } \\
\text { digunakan untuk bercocok tanam tanaman singkong sebagai pekerjaan } \\
\text { sampingan. Secara servis, ruang ini dapat mengakomodasi kegiatan } \\
\text { yang lain saat terdapat perubahan kondisi. }\end{array}$ \\
\hline
\end{tabular}




\begin{tabular}{|c|c|c|c|}
\hline & $\begin{array}{l}\text { Sub- Tatanan } 4 \text { A: } \\
\text { Masjid }\end{array}$ & $\square$ & $\begin{array}{l}\text { Sedangkan pada area ini, perubahan ruang juga terlihat sangat jelas } \\
\text { karena area merupakan sebuah ruang terbuka menyerupai lapangan. }\end{array}$ \\
\hline & & $\square$ & $\begin{array}{l}\text { Lalu secara services, area terbuka pada masjid ini juga menyerupai area } \\
\text { lapangan karena dapat digunakan untuk bermain bola dan bulu tangkis. } \\
\text { Namun pada saat kodisi banjir, ruang tersebut hanya terisi air dan tidak } \\
\text { digunakan secara berkala, berbeda dengan pada saat kondiis kering yang } \\
\text { digunakan setiap hari. }\end{array}$ \\
\hline \multirow[t]{2}{*}{ Movable } & $\begin{array}{l}\text { Sub-Tatanan } \\
1 \mathrm{~B}: \text { Keramba } \\
\text { Apung }\end{array}$ & $\square$ & $\begin{array}{l}\text { Pada area ini, perubahan cenderung berdasarkan pada perubahan } \\
\text { aksesibilitas pada sekitar area transisi pada daerah bantaran sungai. } \\
\text { Dimana pada saat kondisi surut ini, area tersebut merupakan area yang } \\
\text { paling banyak berubah secara aksesibilitas dibandingkan dengan area } \\
\text { lain. Untuk itu bila dilihat, area ini memiliki perubahan struktur dimana } \\
\text { terdapat perubahan infrastrutur dari titian permanen menjadi titian } \\
\text { temporer. Kemudian karena struktur keramba yang dapat mengapung } \\
\text { mengikuti permukaan air maka dikategorikan bahwa elemen pada area } \\
\text { ini dapat berpindah secara site, baik naik turun atau bergerak kiri, kanan, } \\
\text { depan, dan belakang. }\end{array}$ \\
\hline & $\begin{array}{l}\text { Sub-Tatanan } \\
2 \quad \text { A:Rumah } \\
\text { Apung }\end{array}$ & & $\begin{array}{l}\text { Area ini juga merupakan area transisi dimana terdapat jalur sirkulasi dari } \\
\text { titian besar menuju rumah apung. Area ini diklasifikasikan menjadi } \\
\text { movable karena secara struktur kedua elemen yang ada pada area ini, } \\
\text { yaitu titian dan rumah apung dapat berubah mengikuti kondisi } \\
\text { lingkungan yang dinamis. Dan secara site karena titian temporer dan } \\
\text { rumah apung yang dapat mengapung di air, membuatnya dapat } \\
\text { berpindah site, baik secara vertikal dan horizontal. }\end{array}$ \\
\hline
\end{tabular}




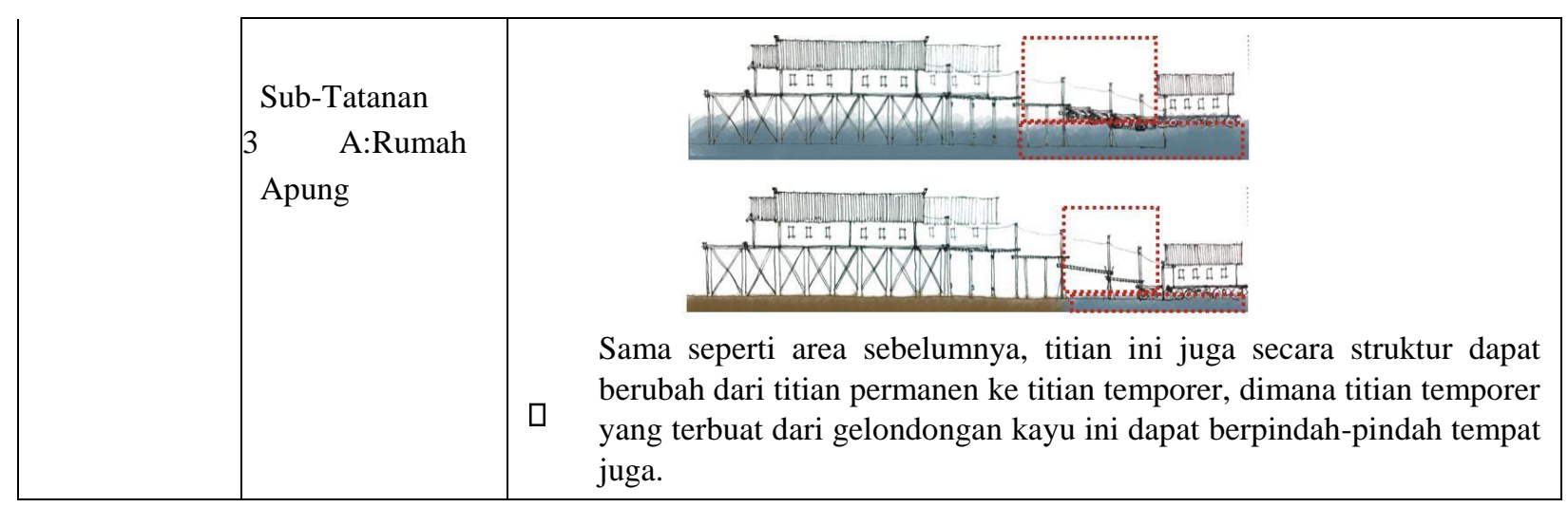

\section{Temuan}

Tenuan pada bab ini dibuat dalam bentuk tabel dengan mengkaji bentuk perubahan apa saja yang terjadi dalam sebuah sub-setting dan bentuk adaptasi apa yang muncul akibat adanya perubahan tersebut.

Tabel 5.

\begin{tabular}{|c|c|c|c|c|c|c|c|c|c|c|}
\hline \multirow{2}{*}{ Setting } & \multirow{2}{*}{ Sub-Setting } & \multicolumn{6}{|c|}{ Atribut Perubahan } & \multicolumn{3}{|c|}{ Bentuk Adaptasi } \\
\hline & & Stuff & Space & Services & Skin & Structure & Site & Adjustable & Refitable & Movable \\
\hline \multirow{2}{*}{$\begin{array}{l}\text { Setting 1: } \\
\text { Lapangan dan } \\
\text { Keramba } \\
\text { Apung }\end{array}$} & $\begin{array}{l}\text { Sub-Setting } 1 \mathrm{~A} \text { : } \\
\text { Lapangan }\end{array}$ & & 0 & 0 & & & & & 0 & \\
\hline & $\begin{array}{l}\text { Sub-Setting } 1 \text { B: } \\
\text { Keramba Apung }\end{array}$ & & & & & 0 & 0 & & & - \\
\hline \multirow{2}{*}{$\begin{array}{c}\text { Setting 2: } \\
\text { Dermaga Polis } \\
\text { dan Rumah } \\
\text { Apung }\end{array}$} & $\begin{array}{l}\text { Sub-Setting 2 A: } \\
\text { Dermaga Polisi Air }\end{array}$ & & 0 & 0 & & & & & 0 & \\
\hline & $\begin{array}{l}\text { Sub-Setting } 2 \text { B: } \\
\text { Rumah Apung }\end{array}$ & & & & & 0 & 0 & & & - \\
\hline \multirow{2}{*}{$\begin{array}{l}\text { Setting 3: } \\
\text { Cocok Tanam } \\
\text { dan Rumah } \\
\text { Apung }\end{array}$} & $\begin{array}{l}\text { Sub-Setting 3 A: } \\
\text { Cocok Tanam }\end{array}$ & & 0 & 0 & & & & & 0 & \\
\hline & $\begin{array}{l}\text { Sub-Setting } 3 \text { B: } \\
\text { Rumah Apung }\end{array}$ & & & & & 0 & 0 & & & - \\
\hline \multirow{2}{*}{$\begin{array}{c}\text { Setting 4: } \\
\text { Masjid dan } \\
\text { Ternak Bebek }\end{array}$} & $\begin{array}{l}\text { Sub-Setting 4 A: } \\
\text { Masjid }\end{array}$ & & 0 & 0 & & & & & 0 & \\
\hline & $\begin{array}{l}\text { Sub-Setting } 4 \text { B: } \\
\text { Ternak Bebek }\end{array}$ & 0 & & & & & & 0 & & \\
\hline
\end{tabular}

\section{KESIMPULAN}

Kampung Pahandut merupakan sebuah permukiman yang terletak di tepi Sungai Kahayan, Kota Palangka Raya. Kondisi sungai yang selalu mengalami perubahan permukaan ketinggian air yang cukup jauh berbeda akibat curah hujan tinggi pada musim hujan menyebabkan permukiman ini akan terendam air pada musim hujan dan mengalami pengeringan pada musim kemarau. Massa bangunan rumah pada permukiman ini yang sudah terlebih dahulu menyesuaikan kondisi ini dibangun dengan sistem panggung agar dapat memberi ruang untuk air pada saat musim hujan. Bentuk rumah panggung seperti ini membuat secara kawasan pada saat kondisi banjir kampung 
akan terlihat seperti rumah apung sedangkan pada kondisi kering rumah akan terlihat seperti rumah panggung dengan kolom-kolom tinggi.

Bila dibahas lebih dalam dan mengikuti perubahan seperti yang dijelaskan Stewart Brand dalam teorinya mengenai Shearing Layers of Change, perubahan yang terjadi pada elemen fisik di Kampung Pahandut dapat diklasifikasikan menjadi 5 perubahan, yaitu: stuff, space, service, structure, dan site. Pada area dengan massa bangunan renggang atau bahkan tidak ada (ruang terbuka), bentuk perubahan tataan ruang cenderung dipengaruhi oleh elemen fisiknya dan hubungannya dengan kondisi banjir dan kering tersebut, sehingga bentuk perubahan yang terjadi adalah perubahan elemen perabot (stuff) ataupun tata ruangnya (space). Selain itu juga karena faktor pengguna yang memanfaatkan ruang tersebut, maka perubahan fungsi (services) juga cenderung terjadi pada area terbuka.

Sedangkan pada bagian kampung lain yang mengalami perubahan adalah pada tataan ruang dengan aksesibilitas tinggi, seperti tataan ruang yang mengalami transisi antara rumah panggung (area tepi sungai) dengan bangunan apung (area diatas air sungai). Pada tataan ruang ini bentuk perubahan yang terjadi cenderung diakibatkan oleh elemen strukturalnya seperti titian dan struktur bangunan apung sebagai respon perubahan kondisi air sungai. Oleh karena itu, pada area transisi ini atribut perubahan yang terjadi cenderung dalam bentuk perubahan struktur (structure) seperti perubahan jenis dan sistem struktur titian kayu yang digunakan sesuai keadaan ketinggian air.

Strategi adaptasi arsitektural yang terjadi di kawasan Kampung Pahandut ini, yaitu adjustable, refitable, dan movable. Berdasarkan temuan, adaptasi arsitektural adjustable ini terjadi pada area-area terbuka yang kemudian dapat dimanfaatkan untuk kegiatan lain namun tidak secara permanen, dimana kegiatan tersebut dapat merespon juga kondisi perubahan lingkungan banjir dan kering. Seperti contohnya pada area ternak bebek, dimana kandang bebek yang menggunakan sistem apung dapat mengikuti perubahan kondisi lingkungan banjir dan kering serta dapat dengan mudah dipindahkan (high mobility furniture).

Kemudian adaptasi arsitektural berikutnya adalah refitable yang paling sering terjadi, dimana biasanya terjadi pada area-area yang pada kondisi banjir maupun kondisi kering samasama dapat mengakomodasi kegiatan, hanya saja kegiatan yang diakomodasi berbeda jenisnya. Adaptasi ini dipicu oleh penyesuaian terhadap kebutuhan akan pemenuhan wadah kegiatan yang dibutuhkan seperti tempat bermain dan kebutuhan akan dermaga ataupun pemanfaatan ruang darat untuk bercocok tanam dengan kondisi lingkungannya, dengan cara menyesuaikan tata letak elemen fisiknya (space plan) agar dapat mengakomodasi fungsi (services) seperti menambahkan net untuk bermain badminton, menambahkan gawang untuk bermain bola, memberi batas-batas lahan cocok tanam, menanam tanaman. Hal tersebut merupakan adaptasi arsitektural yang terjadi pada kondisi kering, sedangkan adaptasi arsitketural pada kondisi banjir adalah penyesuaian sistem dermagayang menggunakan sistem apung dan titian engsel agar dapat mengikuti ketinggian air sungai pada musim hujan.

Terakhir adaptasi arsitektural yang ada adalah movable, adaptasi ini merupakan adaptasi yang terjadi akibat adanya perubahan lokasi. Adaptasi ini dipengaruhi oleh perubahan structure dan site tempatnya berada. Bentuk adaptasi ini juga termasuk yang biasa terjadi karena bila melihat dari bentuk rumah dan titian yang dimiliki kawasan ini merupakan titian temporer yang dapat mengapung juga rumah apung yang keduanya dapat mengikuti perubahan elevasi permukaan air, sehingga merespon adanya perpindahan elemen tersebut jika dibutuhkan. 
Sedangkan adaptasi ini dipicu oleh kondisi lingkungannya terutama sungai dan kondisi tanah di tepian sungai, seperti arus dan kedalaman air sungai yang mempengaruhi dekat dan jauhnya keramba apung serta aksesibilitasnya terhadap rumah panggung. Kemudian pada area rumah apung juga apabila musim hujan, air tinggi dan arus deras maka rumah apung cenderung didekatkan dan diikat baik ke titian atau rumah panggung terdekat. Atau bila saat kondisi kering dimana kondisi tanah cenderung tidak rata di tepi sungai biasanya rumah apung berada jauh dari titian dan lebih dekat ke tengah sungai. Permasalahan akan jarak massa bangunan apung ini selain mempengaruhi letaknya juga mempengaruhi aksesibilitas dan pemilihan jenis dan struktur titian yang digunakan. Dimana bila ingin mudah dibongkar pasang seperti pada keramba apung maka

memilih susunan papan kayu yang ditumpu pada titian permanen. Dan bila pada area rumah apung yang jaraknya cukup jauh biasanya menggunakan titian kayu apung yang juga dapat mengikuti ketinggian air.

\section{DAFTAR PUSTAKA}

Badan Pusat Statistik Palangka Raya. (2013). Statistik Daerah Kecamatan Pahandut 2013. Palangka Raya: Badan Pusat Statistik Palangka Raya.

Chair, Miftahul. (2002). Karakteristik dan Faktor Yang Mempengaruhi Kondisi Permukiman di Kawasan Sekitar Aliran Sungai Martapura Banjarmasin. Tesis.

Ching, D.K. (2007). Architecture Form, Space, and Order 3rd Edition. New Jersey: John Wiley \& Sons Douglas, James. (2006). Building Adaptation: Second Edition. Great Britain: Elsevier.

Lang, Jon. (1987). Creating Architectural Theory: The Role of the Behavioral Sciences in Environmental Design. New York: Van Nostrand Reinhold Company.

Schmidt III, Robert. Austin, Simon. (2016). Adaptable Architecture: Theory and Practice. New York: Routledge.

Wijanarka (2006). Sukarno dan Desain Ibu Kota RI di Palangkaraya. Yogyakarta: Ombak.

Wijanarka. (2008). Desain Tepi Sungai: Belajar dari Kawasan Tepi Sungai Kahayan. Yogyakarta: Ombak.

Hamidah, Noor. Rijanta, R. Setiawan, Bakti. Marfai, Muh. Aris. (2016). Analisis Pemukiman Tepian Sungai yang Berkelanjutan Kasus Permukiman Tepian Sungai Kahayan Kota Palangkaraya.

Lelieveld, Voorbij, Poelman. (2011) Journal: Adaptable Architecture.

Nurfansyah. (2008). Settlement Pattern Model at Riverside: A Case Study of Martapura River.

Priono, Yesser. (2010). Studi terhadap Potensi Tepian Sungai Kahayan menjadi Kawasan Wisata di Kota Palangka Raya.

Purnama, Dina. (2015). Pola Permukiman dan Orientasi Hunian Masyarakat di Pinggiran Sungai Siak. Tesis. 